\title{
The Archimedean Point- Science and Technology in the Thought of Hannah Arendt, 1951-63'
}

\section{Introduction}

In the prologue to The Human Condition (first published 1958), Hannah Arendt described the launch of Sputnik 1 in 1957 as an event 'second in importance to no other, not even to the splitting of the atom' (Arendt, 1998: 1). An awe-inspiring demonstration of scientific and technological power, the Soviet Union's launch of the first artificial earth satellite seemed to challenge natural limits to human activity. Finished within months of this event and drafted at a time of widespread fears of nuclear war, The Human Condition was in part an exploration of the impact of science on human consciousness, shaped by Arendt's anxieties about the survival of politics and culture in the face of technological development, bureaucratic government and 'mass' society. In the last section of the book, Arendt narrated the rise of 'earth alienation', which had led humanity to view the earth from an 'Archimedean point' situated beyond it (Arendt, 1998: 248-89). The eighteenth and nineteenth centuries, she claimed, had seen a qualitative shift from a 'natural' science that exploited natural forces, to a 'universal' science that channelled cosmic forces into nature, rendering obsolete previous understandings of the relationship between the natural and human worlds. The resulting forms of mathematical and calculative thinking were the grounds for contemporary logical philosophy and behavioural sciences, and constituted the primary threat to the hermeneutic forms of political understanding that she valorized. Arendt sought to contest belief in the stable epistemic authority of science, and to challenge the application of scientific methods to politics.

Contemporaries felt that Arendt's treatment of science and technology in The Human Condition contained some of her most arresting insights.1 Since then, however, commentators have largely ignored these preoccupations, treating them as marginal to her thought.2 This essay seeks to rectify this oversight, showing that Arendt's treatment of scientific authority, nuclear weapons and the implications of space flight are vital to understanding her social and political thought. Placing her writings from the 1950s and early 1960s in context, it will show that her narrative of scientific change was tied to thinkers and discourses with which she has rarely been connected. She drew, for example, on the work of the French philosopher of science Alexandre Koyré, and that of American philosophers Alfred North Whitehead and Edwin Burtt. Situating Arendt's writings in this international context, therefore, also sheds light on the transatlantic transfer of discourses on science and technology.

The organizing principle of Arendt's version of the history of science - a divide between natural and human sciences on the grounds of their use of language, and the distance of the former from sense perception - has not dated well, especially in the wake of Thomas Kuhn's path-breaking work on the construction of scientific knowledge (Kuhn, 1962). Arendt was not, however, simply levelling a politicized humanism against scientific values. Instead she posited a historical relationship between science, secularization and the emergence of modern politics. The natural sciences, she argued, had eroded faith in divine revelation, grounding the need for a form of politics that could generate meaning for individuals without relying on theology. The prospects for politics were therefore closely linked to the trajectory of scientific change. The sciences furnished the basis for philosophies of history - such as dialectical materialism - that valorized experimental interventions into nature and society according to scientific laws. They also advanced the technocratic domain of 'the social' that threatened to suffocate free political activity. This essay offers a reconsideration of the basis for Arendt's much-criticized concept of the social from the perspective of her views of science and technology.

To clarify the relationship between Arendt's history of science and her historical and political thought, the first part of this essay examines her treatment of the connection between 
totalitarianism and science in the wider context of German discourses on technology. The second part examines her development during the 1950s of the notion of earth alienation, as she became concerned with the political problems posed by nuclear physics and, by extension, organized scientific inquiry. The third part shows how and why she drew on the reflections of philosophers of science, as well as those of eminent physicists such as Werner Heisenberg, to construct this notion. She filtered her readings through a critical engagement with her most famous interlocutor, Martin Heidegger. While Heidegger was important in shaping Arendt's engagement with conceptions of technology, she critiqued his approach in order to develop her own. Instead of viewing scientific change through the prism of the history of metaphysics, she used it to construct a history of human action. Finally, this essay shows that Arendt drew conclusions from the relationship of science to pluralistic politics and philosophical inquiry in a manner that shaped her conception of the tasks of political theory.

\section{Science, totalitarianism, labour}

Arendt's interest in the history of science and technology was driven by her theory of totalitarianism. As early as 1946 she had argued that modern politics had become suffused by visions of a human world ordered by natural forces, driven by the tendency of modern philosophy to ground existence in biological laws and by increasing faith in the possibility of predicting and controlling human behaviour (Arendt, 2005k: 166; Arendt, 2005i: 195-6). In The Origins of Totalitarianism (1951) she depicted totalitarian movements as the most extreme manifestation of this development. Such movements aimed to create a community whose only freedom would consist in 'preserving the species' (Arendt, 1951b: 305-40, 438). The concentration camp inmate, stripped of juridical and moral personality and reduced to a 'never changing identity of reactions' was the endpoint of this drive (1951b: 99). Biological understandings of humanity were a central feature of the totalitarian imaginary, and therefore a major threat to political culture.3 While her analysis relied on an interpretation of Nazi more than Stalinist ideology, she subsequently placed more emphasis on the wider category of natural laws and less on the field of biology, retrospectively justifying her pairing of Nazism with Stalinism in Origins.

During the 1950s Arendt argued that the idea of universal laws applicable to social organization - encompassing laws of motion and matter as well as evolutionary concepts - was a core feature of totalitarian ideology. In 'Ideology and terror: a novel form of government' (1953), she argued that totalitarian regimes saw themselves as harmonizing positive and natural law in order to allow the laws of race or class to transform humanity into an 'active unfailing carrier of a law to which human beings otherwise would only passively and reluctantly be subjected' (Arendt, 1953: 307).4 Though totalitarianism could not eradicate the human capacity to act freely, it destroyed the norms and institutions sustaining the 'world': the artifice of objects, laws and institutions that grounded political action and separated individuals from nature and one another. The levelling of this artificial world in the name of nature or history modelled on natural processes was the thread linking science to Nazi and Stalinist totalitarianism. Understanding how and why Arendt worked these themes into the history of science and technology found in The Human Condition requires a brief examination of her prior critique of Marx.

Following the publication of Origins, Arendt embarked on an unfinished book project entitled 'Totalitarian elements of Marxism', in which she sought to account for the emergence of Stalinist doctrine from Marxism through a history of the changing status and character of labour and work (Arendt, 1951c). Though she never completed the project, the essays, lectures and notes that resulted prompted The Human Condition, led to several of the essays collected in Between Past and Future (first published1963), and fed into her controversial account of the 
'social question' in On Revolution (first published 1963). There were two central planks to her interpretation of Marx, both of which were based on a questionable reading of his thought. First, she argued, in conceiving of man as a 'labouring animal', Marx had valorised the least elevated of human capacities. As a form of metabolism with nature, the repetitive processes of labour bore a deep resemblance to the directionless and cyclical character of animal life (Arendt, 2005f: 377). By treating the past as a series of struggles to liberate this labouring process from social fetters, he naturalized human history, attributing to it the devoluntarizing aspects of evolutionary science. 5

Second, Arendt argued, Marx combined his view of history with a quasi-Platonic and humanist concept of instrumental action on nature, lauding the capacity of humanity to direct the course of history. Treating history simultaneously as nature and akin to the domination of nature, his thought was therefore easily adapted into Bolshevik and finally Stalinist doctrines mandating the violent transformation of society in the name of a communist utopia (Arendt, 2005g; 1952; 2002a: 282-3). Arendt's argument rested on a problematic separation of Marx's thought into an anti-humanist concept of labour and a humanist concept of work, with the latter understood as a form of Platonic rulership and mastery. The distinction reflected a tension in her project: she sought to reject crude depictions of Marx as a proto-totalitarian while nevertheless linking him to world views central to the emergence of totalitarianism.6 Marx, she argued, prophetically linked the inhumanity of the Industrial Revolution to the vastly increased technical capacities of humanity in politically disastrous ways.

As well as a prehistory of totalitarianism, Arendt's analysis of labour and work in 'Totalitarian elements of Marxism' was an extrapolation from the supposed effects of technological development on modern societies. One outcome of the changes that Marx conceptualized, she argued, might not be Stalinist totalitarianism, but an 'end of history' terminating in the technocratic management of docile populations (Arendt, 2002a: 295; 2005j). This was not a figment of the totalitarian imagination, but an extrapolation of technological development, which with the aid of the model of social sciences, would drive further psychological and sociological change.7 The idea of automation played a central role in Arendt's view of how this might lead to disaster. In 1954 she wondered: 'if labor is the most human and most productive of man's activities, what will happen when, after the revolution, "labor is abolished" ... when man has succeeded in emancipating himself from it?' (Arendt, 2006d: 24). If economic life absorbed individuals wholly into functional labouring or jobholding roles, the automation of labour processes and the ensuing unemployment might make them superfluous in the eyes of society. Without politics to give meaning to lives otherwise immersed in the introspection of private and social life, individuals would be left without an interest in the stability of the human world, and vulnerable to the allure of totalitarian movements (Arendt, 1998: 322).

In The Human Condition Arendt integrated these fears into her notion of 'the social': the conformist, expansionary domain of consumption and production that dissolved the boundaries between private and public life (Arendt, 1998: 41). The product of nineteenth-century social and economic development, she argued, the social precipitated the decline of public spheres and republican values in favour of a vision of politics as the management of the "national household' (1998: 38-49, 44). She had modified her theory of the conditions for totalitarianism to account for the post-war prosperity of the United States and Western Europe. She was also critiquing the optimistic prognoses of liberal 'end of ideology' thinkers such as political theorist Daniel Bell and sociologists Talcott Parsons and Edward Shils.8 This critical intent was especially evident from her assessment of the behavioural sciences in The Human Condition. Far from being unrealistic fantasies about the harmony of individual self-interest with economic development, Arendt argued, the behavioural sciences were 'the best possible conceptualization' of these trends (1998: 322). In presaging the reduction of humans 'to the 
level of a conditioned and behaving animal', the behavioural sciences were ideally suited to the devolution of government to 'pure administration', a process that had been gathering pace since the development of the bureaucratic national welfare state $(1998: 45,322)$.

Arendt circumscribed the range of possible responses to these developments through her critique of socialism and assessment of the effects of secularization, framed by her view of the effects of science and technology. Her narrative of the decline of Homo faber, the utilitarian 'creator of the human artifice', was an implicit critique of mechanistic socialist humanism (1998: 139).9 Homo faber rose with the Industrial Revolution, but its prestige as a social model declined in the nineteenth century as a result of the nihilism of its instrumental means-ends categories, which led to a 'degradation of all things into means, their loss of intrinsic and independent value' (1998: 156). This relativization of values revealed the absence of any meaning other than usefulness at the heart of instrumental attempts to build a comfortable home for humanity on earth. Without a higher source of meaning, technology and industrial modernity engendered mass societies dominated by the individual and collective instrumental pursuit of interests, with the spare time of the working individual 'never spent in anything but consumption' (1998: 133). This led to the 'grave danger that eventually no object of the world will be safe from consumption and annihilation through consumption' (1998: 133).

Though Arendt presented her argument as a philosophical criticism of the circularity of utilitarianism, coupled to a critique of mass society, it was based on her writings on Marx's concept of work, which she now tied to her view of secularization. She referred to the selfunderstanding of Homo faber as 'lord and master of the whole earth' (1998: 139). His creativity was seen in the 'image of a Creator-God ... where God creates ex nihilo, man creates out of given substance' (1998: 139). As a result, human productivity necessarily led to 'a Promethean revolt because it could erect a man-made world only after destroying part of God-created nature' (1998: 139).10 Secularization together with technological development allowed the attribution of divine capacities to human beings. Implicitly rebutting optimistic treatments of secularization and modernization found in the social sciences, Arendt suggested that instead of leading to a new secular worldliness in opposition to Christian belief, modernity instead threw man into inward introspection and radically alienated him from the world (Arendt, 2005f: 36872). The result was a new anthropological stage in human development.

\section{The question of technology}

As well as adapting theories of mass society, in treating technology as a political problem Arendt was participating in a widespread and longstanding European discourse that presented it as a force that was not amenable to human control.11 Such notions were a feature of cultural life in all the countries - France, West Germany and the United States - in which she spent significant amounts of time during the 1950s. They were particularly prevalent in Germany.12 During the 1920s and 1930s, intellectuals such as Ernst Jünger and Oswald Spengler had denounced the materialism and nihilism of technologically driven mass society, casting Soviet Russia and America as standard-bearers for these developments, and as the principal threats to the role of Germany as custodian of European culture.13 Heidegger took a similar line. In Einführung in die Metaphysik (1953), the published version of lectures he originally delivered in 1935, he qualified a laudatory reference to the 'inner truth and greatness' of National Socialism with the claim that its greatness lay in staging an 'encounter between global technology and modern humanity' (Heidegger, 1953: 152). In Arendt's copy of the text this phrase is underlined.14 Europe, Heidegger argued, lay 'in the great pincers between Russia on the one side and America on the other', both representing 'the same hopeless frenzy of unchained technology' and 'rootless organization of the average man' (Heidegger, 2000: 40). 
Though intellectuals in West Germany after the Second World War continued to draw close connections between the hegemony of the United States and global technological development, following the integration of Germany into American-led political and military alliances, critiques of technology became less imbued with anti-democratic and antiWestern sentiment.15 Idioms of German exceptionalism declined as the perceived axis of global struggle swung from German Kultur versus shallow Western Zivilisation to political freedom versus communist unfreedom. 16 This was a shift to which Arendt had contributed: while occasionally discussing German culpability for totalitarianism, she also analysed it as a European phenomenon that could not be reduced to the idiosyncrasies of German history (Arendt, 2005a).17 Geopolitics and the burden of the Nazi past encouraged German intellectuals émigrés such as herself included - to treat technology less as a point of differentiation within Western Europe and between Europe and America, and more as a feature of modernity.

Occupying an interstitial position between the two continents, Arendt argued that though European fears about American power were misdirected, they merited attention as indicators of wider historical change. In a trio of essays published in 1954 in the lay Catholic journal Commonweal, she claimed that the "process which Europeans dread as "Americanization", involving runaway economic growth and mass culture, was 'the emergence of the modern world with all its perplexities and implications' (Arendt, 2005j: 426). The central problems of the contemporary world, she argued, lay in 'the political organization of mass societies' and 'the political integration of technical power' (2005j: 427). These convictions structured The Human Condition. On the prospect of technocratic political rule, she wrote in her concluding statements to the book: 'It is quite conceivable that the modern age - which began with such an unprecedented and promising outburst of human activity - may end in the deadliest, most sterile passivity history has ever known' (Arendt, 1998: 322). The most salient influence on this pessimistic assessment was Max Weber's Die Protestantische Ethik und der Geist des Kapitalismus (1904), particularly his depiction of the 'shell as hard as steel' formed by modernity around the individual by the demands of socio-economic life. 18

Arendt was also critically engaging with Heidegger's writings on technology. Though his turn from ontological matters in metaphysics to cultural questions had been in train since the early 1930s, his renewed influence on Arendt was most marked from 1953, the year in which he delivered the lectures 'Die Frage nach der Technik' and 'Wissenschaft und Besinnung', and oversaw the first publication of Einführung in die Metaphysik.19 Arendt's interests had at this time begun to drift away from Marxism and towards the wider history of modernity. In a survey paper on European thought she delivered at a meeting of the American Political Science Association in 1954, she suggested that Heidegger's concept of 'historicity' provided a mode of philosophical and historical analysis suited to examining the processes that constituted modernity (Arendt, 2005b: 432-5).

Historicity, Arendt argued, linked insights into the temporally bound 'structures of human life' to historical change without subordinating either to the revelation of a Hegelian absolute. Hence Heidegger was

\footnotetext{
highly sensitive to general trends of the time, to all the modern problems that can be best understood in historical terms, such as the technicalization of the world, the emergence of one world on a planetary scale, the increasing pressure of society upon the individual, and the concomitant atomization of society. (Arendt, 2005b: 433)
}

Her summary amalgamated Heidegger's earliest discussions of technology in 1935 with his most recent lectures from 1953. In Einführung in die Metaphysik, Heidegger had written that when the farthest corner of the globe has been conquered technologically and can be exploited economically; when any incident you like, in any place you like, at any time you like, becomes accessible as fast as you like', then time became 'nothing but speed, instaneity, and 
simultaneity, and time as history has vanished from all Dasein of all peoples' (Heidegger, 2000: 40). Arendt echoed some of these claims in The Human Condition; describing, for example, the relationship between technology, motion and history through the 'apparently limitless economic accumulation process' (Arendt, 1998: 250).

Arendt was not simply reiterating Heidegger's treatment of technology. In her 1954 paper she had argued that historicity was fundamentally problematic for the study of history due to its neglect of 'the center of politics - man as an acting being' (Arendt, 2005b: 453). Historicity avoided the 'permanent questions of political science' such as 'What is politics? Who is man as a political being? What is freedom?' (2005b: 433). Heidegger, she argued, could grasp world-historical processes, but not the political character of the 'world' that was in the process of being lost. Rather than treating science and technology in terms of unfolding essences, Arendt sought to stress their contingent development as part of a parable about the unpredictability of human action. Though still concerned with totalitarianism, she was responding to a political and cultural situation dominated by horizons of technological change rather than the immediate threat of barbarism, seeking to account for what she argued were the real social, economic and perceptual shifts that had collapsed the distinction between nature and the human world, as opposed to the ideological glosses on that reality found in Nazi biologism or Marxian labour. By the mid 1950s she thought that the importance of technology had gone much beyond the "nowfamiliar debates about the soullessness of a country dominated by modern technology, the monotony of the uniformity of a society based upon massproduction' (Arendt, 2005d: 418). The advent of quantum mechanics, nuclear power and spaceflight marked a new epoch. Arendt's suggestion that 'now-familiar debates' needed to be superseded must be understood in the specific context of nuclear power (2005d: 418).

\section{Nuclear power: the bomb that will bring us together}

Arendt's view that contemporary science had entered a new stage of development with important political consequences was shaped by the prominence of scientific research in postwar public life. The Second World War had seen enormous increases in federal funding for practice-oriented research projects in the United States. As tensions with the Soviet Union heightened, money flowed into organizations and agencies such as the Atomic Energy Commission and the National Science Foundation, and scientists figured increasingly in public life (Leslie, 1993: 133-59).20 Equally prominent in the popular imagination, however, were fears of atomic warfare (Carson, 2010b: 491). Positioned between European and American publics, throughout the 1950s Arendt reflected on the implications of the intertwined political and technological circumstances of the two continents. Particularly affected by uncertainty in Germany about the interpenetration of scientific research, technology and politics, in 1954 she noted that a major driving factor in this was the European fear of nuclear destruction (Arendt, 2005j: 426).

Arendt's closest interlocutor on the political ramifications of atomic weapons was Karl Jaspers (Young-Bruehl, 1983: 300).21 Despite noting that the destructive power of the bomb was such that its use could not be countenanced, in an important 1951 essay Jaspers did not make a case for an outright anti-nuclear stance. It was inconceivable, he argued, that a world that tolerated 'forced labour in concentration camps, deportation of entire population groups ... planned extermination of entire peoples' would be able to eliminate nuclear weapons on a moral basis, especially when past failed attempts to ban destructive weaponry were taken into account (Jaspers, 1951:314-15). He was not, however, wholly pessimistic. The destructiveness of nuclear weapons might spur a moral transformation in society; only this could make an end to the bomb possible, or even desirable, given the totalitarian threat. Jaspers' ambivalence reflected international circumstances: he understood the bomb in part as an unfortunate but 
necessary instrument to defend Europe from Soviet expansionism (1951: 314-15). As even more destructive hydrogen bombs were tested by the United States and the Soviet Union, and civilian uses for atomic energy mooted, Jaspers fleshed out his stance.

In a radio broadcast in 1956, extended and published as Die Atombombe und die Zukunft des Menschen (1958), Jaspers expanded on the position he took in 1951.22 Insisting on disarmament as a precondition for peace - his book was awarded the Peace Prize of the German book trade - he nevertheless made a fundamental distinction between Western freedom and expansionist Soviet totalitarianism that made unilateral disarmament impossible. For the time being, the only alternative to living with the atom bomb was 'Total Rule' (Jaspers, 1961: 11011, 160-73). For his stance he was heavily criticized by opponents of German rearmament. He was intervening in a fraught nexus of politics, physics and nuclear technology. In 1953, as part of its 'New Look' policy, the United States government had proposed placing large numbers of nuclear weapons in Western Europe, buttressing a strategy of 'massive retaliation' in the event of Soviet aggression (Gaddis, 2005: 125-96). In 1957, the German government announced that it might be necessary to arm the Bundeswehr with some of these weapons. Amid increasing controversy, a group of physicists subsequently known as the 'Göttingen Eighteen' joined to condemn the policy of nuclear deterrence, splitting public opinion. Despite much support, many Germans regarded them as naïve at best and treasonous at worst (Beyler, 2003: 232-4). Jaspers agreed that deterrence was untenable in the long run, but asserted that in the short run the scientists were being politically irresponsible (Jaspers, 1961: 160-73; Carson, 2010a: 325-6).

While sharing some common ground with Jaspers' position on nuclear weapons, as she explained in a 1955 letter to her husband Heinrich Blücher, Arendt was more forthright in her criticism of the rationale for nuclear weapons. In 1954 she had criticized the principle of retaliation embedded in NATO policy, arguing that the consequences of nuclear warfare, even conducted by the 'American Republic', would destroy political life and nullify freedom (Arendt, 2005d: 420). Deterrence neglected the unpredictability of politics. She expressed sympathy with the anti-nuclear movement in Germany - whose ranks included her ex-husband, Günther Anders - that Jaspers criticized (Dijk, 2000: 52-61).23 Shortly before the publication of Jaspers' book in 1958, she wrote to Blücher: 'Here in Germany, nothing but nuclear unrest; I am surrounded by people who see it as hysteria and manoeuvring by the Social Democratic Party. I disagree' (Arendt and Blücher, 2000: 318). Nevertheless, she argued that the 'totalitarian world' was reconciled to the possibility that any future large-scale war would 'harbour a threat of destruction to the existence of mankind, even to the existence of organic life on earth' (Arendt, 1958b: 20). Despite her sympathy for the anti-nuclear movement, she shared Jaspers' conviction that deterrence and the bomb were contemporary geopolitical facts that could not and should not be reversed.

The bomb also betokened an 'atomic era' of wider import. Arendt and Jaspers feared that by reducing the need for labour, atomic energy would accelerate processes leading to the 'superfluity' of individuals who, as Jaspers put it, might succumb to 'rage at a liberation that destroyed the traditional ways of work and life' (Jaspers, 1961: 178-9). Neither, however, saw this era as a straightforward extension of the technical development of mass society; the threat of total annihilation set it apart. Jaspers, arguing that the world peace required for the elimination of the bomb 'cannot be achieved in laws and treaties alone ... without a change in man', suggested that the threat might bring about radical ethical action and the founding of cosmopolitan and philosophically grounded republics (1961: 187). Arendt, though less sanguine, expressed a similar hope. 'By putting in jeopardy the survival of mankind and not only individual life or ... the life of a whole people', she argued, the atom bomb might 'transform the individual mortal man into a conscious member of the human race, of whose immortality he needs to be sure in order to be courageous at all and for whose survival he must 
care more than for anything else' (Arendt, 2005c: 422). If totalitarian attempts at world domination had brought about the recognition of a common humanity, the bomb might turn individuals into universal beings forced to view the political world from the perspective of mankind.

The idea that atomic danger might bring new possibilities in man's relationship with nature and technology was also expressed by Heidegger. In 'Die Frage nach der Technik' he suggested a relationship between extreme danger - though not to be understood in the literal sense of nuclear devastation - and a 'saving power' that would allow humans to gain an authentic relationship with technology and the world (Heidegger, 1954: 99-100). Yet the notion of historicity that framed his approach, Arendt argued, neglected the contingency of the historical developments that defined man's present relation to technology, and their beginnings in human action (Arendt, 2005b: 433). For similarly political reasons, she found Jaspers' response to the nuclear age unsatisfactory. Writing to Blücher in 1958, she described Die Atombombe und die Zukunft des Menschen as 'an exceptional book', but added: 'if he would only refrain from all the moralizing; but he can't, that's precisely what is most important to him' (Arendt and Blücher, 2000: 331). She had previously chided Jaspers for his substitution of ethics for politics in discussing German guilt, something Blücher had also found infuriating (Rabinbach, 2000b: 148-52). By the mid 1950s, the political problems raised by nuclear weapons had encouraged Arendt to balance moralizing on the dangers of new technology with a historical understanding grounded in theoretical physics and the history of science. In The Human Condition she presented a philosophical and historical investigation of the relationship between human beings and nature, framed by contemporary physics and the belief that the universal perspective now forced upon politics was tied to the emergence of 'universal science' through 'earth alienation' (Arendt, 1998: 268-325).

\section{Earth alienation and the history of science}

Though Arendt wrote her history of science with a characteristically German emphasis on techne, convinced that atomic energy signalled a new era in man's relationship with nature and the world, she also had the opportunity to sharpen her understanding of the scientific dimensions of modernity in a new intellectual environment. Teaching at Berkeley at 1955, she attended lectures by the Gestalt psychologist Wolfgang Köhler on the relationship between psychology and physics (Leslie, 1993: 141, 148). Though uncharitably referring to him as 'that jackass Köhler', she found his lectures interesting, and remarked to Blücher that her understanding of physics was improving (Arendt and Blücher, 2000: 243). She would also have been aware that Berkeley and the Radiation Laboratory it managed for the United States Department of Energy were major centres for physics research. The following year she began collecting American and German press clippings on a range of scientific issues ranging from astronomy, germ plasma, hydrogen fusion and, after the launch of Sputnik, the 'space race' (Arendt, 1951a). These interests shaped The Human Condition.

As scholars have noted, The Human Condition is focused less on politics itself than on the spaces necessary for its practice (Canovan, 1994: 99-154; Pitkin, 1998). In narrating how these spaces had become swamped by large-scale social and economic processes, Arendt was also presenting a cautionary history of the human capacity for action, which she argued had increasingly been channelled into scientific endeavour as 'action into nature', setting off unpredictable processes while fostering illusions of instrumental control (Arendt, 1998: 52). At the root of these changes lay the development of earth alienation (1998: 264). Arendt's conception of 'earth', devoid of connotations of place, dwelling or homeliness reflected a wariness of valorizing 'blood and soil' and eliding the distinction between the human and the natural (1998: 256; Macauley, 1996: 103-4). She instead attached these characteristics to her 
humanist concept of the 'world' (Arendt, 1998: 7). Though influenced by Heidegger's criticism of modern representations of the world as a Weltbild, she was careful to distinguish between world and earth alienation, and in historicizing the latter, shied away from granting the earth any originary meaning prior to its alienation (1998: 7). Arendt only discussed the earth in the alienated sense she claimed it had been given by early modern science: located in universal space and measured or viewed from a perspective outside itself (Macauley, 1996: 108; Arendt, 2005b: 432).

Though Arendt described them as of 'minor significance' in comparison with earth alienation, the two other forms of alienation that she referred to in The Human Condition inner and world - are essential to understanding her notion of earth alienation (Arendt, 1998: 264). Rooted in her critique of Marx's concept of labour and work from 'Totalitarian elements of Marxism', they formed the core of her account of modernity. World alienation, 'produced in the twofold process of expropriation and wealth accumulation' following the Reformation, saw peasant and church lands expropriated and sucked into globalizing markets (1998: 264). These changes, accelerated by the Industrial Revolution, were grounded in repetitive, quasibiological processes of labour that undermined the permanence and stability of the human world by absorbing worldly objects - tools, clothing, dwellings - into cycles of production, consumption and obsolescence (1998: 118-35). While her narrative reflected a sympathetic view of Marx's political economy, Arendt's concepts of world and inner alienation owed more to Weber, in particular his notion of 'inner-worldly asceticism' from Die Protestantische Ethik (Weber, 1904:

53-125).

To illustrate inner alienation, Arendt referred to the 'withdrawal from terrestrial proximity' fostered by cartography and the exploration of the world, which put 'a decisive distance between man and earth ... alienating man from his immediate earthly surroundings' (Arendt, 1998: 251). This was estrangement from the natural and human world rather than Marxian alienation from the product of one's labour (Arendt, 2002b: 106, 112). Inner and world alienation encouraged a flight 'from the whole outer world into the inner subjectivity of the individual, which formerly had been sheltered and protected by the private realm' (Arendt, 1998: 52). The result was the 'modern discovery of intimacy' that drove nineteenth-century Romanticism and more recent popular psychological speculation on 'inner life' in mass societies (1998: 69).24 Arendt's depiction of the effects of social and economic change on human consciousness was a history of the present: both communist and democratic societies albeit to differing degrees - prioritized economic growth while rejecting the need to sustain public spaces for political action, the only sure bulwark, in her view, against totalitarianism (1998: 31).

Earth alienation overlapped chronologically and thematically with inner and world alienation, beginning with the exploration of the world and the invention of the telescope. The invention of the telescope in particular, Arendt argued, spurred the development of modern science, premised on the adoption of the 'Archimedean point', a subject position lying outside the earth (1998: 248, 262-3, 284-5). To explain this, she drew on sources in the history and philosophy of science, especially the work of American philosophers Edwin Burtt, Alfred North Whitehead and, above all, the French philosopher of science Alexandre Koyré. Having met in the 1930s in Paris, during the 1950s Arendt and Koyré met again several times and exchanged regular correspondence (Arendt, 1951d). Her narrative of the history of science drew extensively on his From the Closed World to the Infinite Universe (Koyré, 1957).25 The similarities in the framework with which they approached the history of science can be seen in the opening pages of Koyré's book.

In terms Arendt would draw upon to depict the effects of world alienation, Koyré declared his intention to historicize the changes in the seventeenth century that led to man losing 'his 
place in the world, or more correctly ... the very world in which he was living' (Koyré, 1957: viii, 2). He examined the changes wrought by Copernicus, Galileo, Newton and other figures in early modern philosophy and science, leading to the eclipse of a closed, ordered notion of the world by a conception of the universe characterized by never-ending geometrically understood space (Koyré, 1957: viii). During 1956 and 1957, Arendt began to read many of the works of early modern science and contemporary commentaries used by Koyré for his argument, taking notes in particular on Copernicus' On the Revolutions of the Celestial Spheres (1543), Kepler's The New Astronomy (1609) and Galileo's The Starry Messenger (1610) (Arendt, 1956: mss. 027308, 027310-027317, 02789-027293).

In 'The vita activa and the modern age', the final section of The Human Condition, Arendt acknowledged that she was in part following Koyré's argument. Copernican astronomy, she claimed, had 'needed no telescope to assert that, contrary to all sense experience, it is not the sun that moves around the earth but the earth that circles the sun' (Arendt, 1998: 258; Koyré, 1957: 34-5). Though the heliocentric system was ancient, the philosophical speculations of Nicholas of Cusa and Giordano Bruno and the 'mathematically-trained imagination' of the astronomers Copernicus and Kepler were vital in mounting a vigorous new challenge to 'the finite, geocentric world-view which men had held since time immemorial' (Arendt, 1998: 258). A historian looking for the unfolding 'of ideas with predictable courses', Arendt argued, might therefore conclude that empirical confirmation was unimportant in discrediting the geocentric system. Like Koyré, Arendt thought that the astronomy of Kepler and, most importantly, Copernicus in his Siderus Nuncius (1610), marked a decisive shift away from geocentric conceptions of the universe (1998: 258).

Arendt placed more stress than Koyre on the role of the telescope in aiding the ascent of heliocentrism. Drawing on Burtt's claim in The Metaphysical Foundations of Modern Science (1932) that the influence of philosophers such as Giordano Bruno was felt only after the telescope confirmed the claims of their speculations, she argued that its invention and use brought about the early modern abandonment of geocentrism and constituted 'the decisive event of the modern age' (Burtt, 1932; Arendt, 1998: 273). She was applying her category of 'event' to the history of science (Arendt, 2005k). For Arendt, events were constellations of human acts and unpredictable consequences, inexplicable through causality alone, but capable of beginning chains of further events that allowed the identification of an 'unbroken continuity, in which precedents exist and predecessors can be named' (1998: 248). The telescope, and Galileo's subsequent discoveries - alongside the discovery of the Americas and exploration of the earth - were events, but not in the same way as political phenomena such as the French Revolution. At the start of 'The vita activa and the modern Age', Arendt uses the French Revolution as an example of a quintessential modern 'event' (Arendt, 1998: 248). Earth alienation revolutionized man's relationship with nature and the world through scientific action. Arendt described a modern form of action that had superseded that found in the ancient world of the polis.

Perhaps the greatest change wrought by these developments, she argued, was the shift from a 'natural' to a 'universal' science. The erosion of geocentrism allowed the circumvention of the sensory limitations of the body, enabling the observation and explanation of nature as if from an 'Archimedean point' located outside the earth. This innovation, clarified in philosophical language permeated by scientific terminology, allowed humans to conceive of themselves as moving 'freely in the universe, choosing our point of reference wherever it may be convenient for a specific purpose' (1998: 263). While inner alienation sanctioned a withdrawal from terrestrial proximity, earth alienation positively demanded that 'man orient himself from the universal standpoint, the Archimedean point lying outside the world' (1998: 264). The resulting drive to mastery of the earth was a rejection of aspects of the human condition that entailed humans being earthbound and subject to contingency. It enabled 
enormous technological advances, subjecting the earth and mankind itself to human control, and ultimately prepared the way for nuclear technology and spaceflight (1998: 257-68).

These changes marked a shift from Aristotelian notions of nature to mechanistic and mathematized hypotheses underwritten by the practices of experimental science. While claims concerning the neo-Aristotelian tenor of Arendt's political thought have been overstated, she was undoubtedly committed to the idea of political communities rooted in a stabilizing relationship with nature.26 The polis was one such form of community, but similar sentiments also shaped the contrast she drew between modern science and the stable relationship between natural and human domains found in the ancient world. Prior to the telescope and modern experimental science, Aristotelianism had understood nature as purposive and embedded in qualitatively differentiated space (1998: 259).27

Earth alienation supplanted Aristotelian conceptions with an understanding of nature as a range of universal processes located in infinite and homogeneous space. Arendt took the radical disregard of the Galilean method for the sensual and material reality of nature as axiomatic, promising to deliver 'the secrets of the universe' to cognition 'with the certainty of senseperception' (1998: 259-60).28 These changes in thought were accompanied by experimental practices that prescribed 'man-thought conditions to natural processes and forced them to fall into man-made patterns', recreating them in the laboratory (1998: 231). Arendt's reference points were Francis Bacon and Isaac Newton. 'In the experiment', she wrote,

man realized his newly won freedom from the shackles of earth-bound experience; instead of observing natural phenomena as they were given to him, he placed nature under the conditions of his own mind, that is, under conditions won from a universal, astrophysical viewpoint, a cosmic standpoint outside nature itself. (Arendt, 1998: 265)

Koyré had claimed that geometrical and mathematized conceptions of the world had resulted in 'the utter devalorization of being, the divorce of the world of value and the world of fact' (Koyré, 1957: 2). Arendt agreed, but rather than lingering on the loss of meaning and value in a scientifically understood world, she discussed new sources of meaning derived from nature that had shaped modern understandings of history and action. Drawing on Whitehead's claim that 'nature is a process', she made the notion of 'processes' central to this new meaning and action produced by experimental science (Whitehead, 1920: 53, 15, 66; Arendt, 1998: 296).

The need for experiments to recreate "the process of "making" by which natural objects came into existence' fostered an understanding of the world in terms of processes. The question of 'what' in classical science, enquiring into the meaning of objects, was replaced by the investigation of 'how', exploring the origins and causes of motion of phenomena in an attempt to discover universally applicable laws (1998: 296). This experimental mode of investigation filtered into historical understanding, especially as the growing tendency to view earth from an 'Archimedean point' encouraged the treatment of the natural and human worlds as a unified domain, subject to the same laws and part of the same historical process (1998: 249). As a result, 'man began to consider himself part and parcel of the two superhuman, allencompassing processes of nature and history, both of which seemed doomed to an infinite progress without ever reaching any inherent telos or approaching any preordained idea' (1998: 307). The passing of the Aristotelian concept of nature saw the distinction between natural and human domains break down.

Arendt's radicalization of Whitehead's depiction of nature as a process was tied to her epochal claims about the relationship between politics and technology and nature and history. She outlined these in 'The modern concept of history' (1958). During the modern age, she argued, man had sought to 'act into history' as if history consisted of phenomena suitable for experimentation (Arendt, 1958a: 586, 588-9). While she saw a belief in the absence of boundaries between nature and humanity as characteristic of totalitarianism, the behavioural 
sciences suggested to her that the prestige of the natural sciences continued to accompany a dehumanizing universal perspective on human life. The twentieth century had also seen a qualitative shift in the view that what could be done in history could also be done in the natural domain; natural processes could be begun by human beings. Where totalitarians had defined freedom fallaciously as the ability to intervene in the purported natural or quasi-natural processes shaping humanity, nuclear physics threatened to break down the world, by actually starting cosmic and natural processes and channelling them into the natural realm (1958a: 586). This, Arendt, argued, was the hallmark of the atomic era.

By the mid 1950s totalitarianism seemed less threatening to Arendt than hydrogen fusion, whose implications were clear from the first hydrogen bomb tests by the United States in 1952 and the Soviet Union in 1953. By 1954, attempts to harness the energy produced by hydrogen fusion for civilian use were receiving significant attention from the press. In West Germany, leading scientists including Werner Heisenberg - who, as we shall see, would be a major influence on Arendt's reading of modern science - made advances in fusion research at the Max Planck Institute of Physics.29 The process of releasing energy through the fusion of hydrogen into helium, she noted, replicated processes that took place in the sun; it appeared to transcend the limits of the natural world as given to human beings (Arendt, 1998: 231). The acceleration of earth alienation and pre-eminence of notions of process dominated the atomic era. Treating these developments as irreversible, Arendt did not suggest a return to Aristotelian forms of understanding nature that might parallel the Greek view of the polis. Instead she looked for an answer to the 'universal perspective' from within the history of universal science. She would find one in the development of modern physics.

\section{Physics and politics}

Arendt constructed a history of science in The Human Condition not only to account for changing conceptions of natural and historical processes, but also to understand secularization and historicize modern philosophy. She sought to argue that just as the behavioural sciences undermined the possibility of action by encouraging individuals to conform to certain standards of behaviour, modern philosophy also undermined the possibility of a freely roving 'common sense' that could stabilize political interaction (Arendt, 1998: 280-3). Modern philosophy, she argued, was rooted in what Koyré described as 'the old ideal of the vita contemplativa yielding its place to that of the vita activa', tending to privilege action over contemplation or wonder at the divine (Koyré, 1957: 1). This tendency did not arise from secularization understood as 'a sudden, mysterious dwindling of faith in God', but rather from the transition from speculative to experimental science. Because science suggested that nature required its secrets to be teased out through experimentation, there was a loss of confidence in the "truth-revealing capacity of the senses'. Philosophers like Descartes expressed a growing 'despair of ever experiencing and knowing adequately all that is given to man and not made by him' (Arendt, 1958a: 283, 589). Common sense no longer referred to the relationship of private senses to a shared world, but to a shared structure of mind (Arendt, 1998: 280-4). Yet, confronted by the new understanding of man's place in the universe implied by Galileo's discoveries, Descartes coupled this solipsistic form of subjectification with a hubristic analytical geometry, premised on the possibility of taking an epistemological standpoint outside the earth. The result was the placement of the 'Archimedean point' within man (1998: 266).

The passage from natural to universal science, Arendt argued, produced a mix of subjectivism and objectivism in philosophy that when combined with the materialism produced by world alienation, encouraged visions of political action premised on violently ordering the world, grounded in the instrumental, fabricating impulses of Homo faber (1998: 584). Under the conditions of mass society this had contributed to totalitarianism. A less often considered 
development that Arendt associated with these changes, however, was the mathematization of the world brought about by shifts in cognition, fostered by earth alienation. Here she drew in particular on Edwin Burtt's treatment of the philosophical consequences of the 'reduction of terrestrial motions to the terms of exact mathematics' (Burtt, 1932: 63).

Universal laws governing natural and human worlds, Arendt argued, required mathematical innovations that allowed non-sensible standards and measurements to be presented to the mind as if they were sense data. In line with Descartes' transfer of the locus of experience to inner consciousness, mathematics reduced sensory data and worldly phenomena 'to the measure of the human mind' (Arendt, 1998: 267). When she criticized the social sciences - in particular behaviouralism - for adopting the categories of the natural sciences to treat human phenomena, she was referring to this emphasis on quantifiability (1998: 42-3, 178). Whereas in Origins and 'Totalitarian elements of Marxism' she had used biological and evolutionary metaphors to describe the effects of natural science on human understanding, in the late 1950s she turned to a mathematized reading of physics.

Logical positivism and, more broadly, the emerging disciplines of analytical philosophy formed the background for Arendt's claims. The logical empiricism pioneered by members of the Vienna Circle such as Otto Neurath, Hans Hahn and Rudolf Carnap, positing the construction of theories from linguistic frameworks tied to the neutral observation of scientific phenomena, was in part a reaction to the popularity of ambitious ontological projects pioneered between the wars by figures like Heidegger and Max Scheler (Isaac, 2005: 225-6). At the same time as she was learning about physics in Berkeley in 1955, Arendt had sent a letter to Jaspers dismissing the philosophy faculty as engaged in 'semantics ... and even that is third-rate' (Arendt and Jaspers, 1992: 251-2). By emphasizing the roots of mathematically rigorous logical philosophy in a natural science that depended on artificial experimental conditions, Arendt sought to emphasize the inability of these approaches to relate to worldly concerns. With 'the disappearance of the sensually given world', she claimed, 'the transcendent world disappears as well, and with it the possibility of transcending the material world in concept and thought' (Arendt, 1998: 288). Contemporary philosophy, Arendt argued, impoverished the ways in which humans related to their surroundings by mathematizing the relationship of consciousness to phenomena.

Mathematization made science dependent on the 'devices of modern algebra', rendering the language in which scientific discoveries were articulated opaque (1998: 261, n16). Science and politics were unable to communicate with one another, not because of inadequate public education, but due to the character of modern science. This was a dangerous problem because, through organization, scientists had long generated the power to act collectively to set off unpredictable processes that traversed the human and natural world. 'No scientific teamwork', she noted, was 'pure science' (1998: 271). However, rather than acting from within webs of human relationships ensconced in the world - the way she conceptualized political action scientists took the alienated standpoint of a universal science acting on the world and earth, articulating themselves in a mathematical language that isolated their actions from political deliberation (1998: 324). While using the example of the Royal Society in the seventeenth century, a likely contemporary context for her point was the Göttingen Eighteen controversy over nuclear deterrence unfolding in Germany in 1957, blending the dangers of hydrogen fusion with those of the interface between politics and science. Though making no public comment on the controversy, Arendt's conversations with Jaspers and comments to Blücher on his intervention into the debate suggest that it was not far from her mind (Arendt and Blücher, 2000: 287).

The stress Arendt laid on mathematics and physics as a weathervane for the relationship between science and politics emerged from a nexus of politics, fear of nuclear weapons and the role of science in public life. Despite her claims about the deleterious effects of the 
mathematization of physical space and language, she portrayed contemporary physics in an almost positive light. She regarded the 'revolution' in twentiethcentury physics as the harbinger of a new age in man's relation to science and the natural world. At the heart of this claim lay a reading of Heisenberg's Das Naturbild der heutigen Physik (1955) which she used to claim that theoretical physics implied that the existence of a mind-independent natural world was reciprocally dependent on the cognition of the observer (Arendt, 1998: 261-2; Heisenberg, 1955).

Heisenberg's uncertainty principle, Arendt claimed, suggested limits to the accuracy of measurements when examining particles, as they could not be observed without being disturbed by the observation process itself (Arendt, 2006c: 271-2; Arendt, 1998: 261). The objective reality of particles, among the smallest building blocks of the universe, could not be understood apart from the action of the observer. What were being objectified in the observation process, therefore, were not particles, but human knowledge of them. She quoted Heisenberg: 'man, whenever he tries to learn about things which neither are himself nor owe their existence to him, will ultimately encounter nothing but himself, his own constructions, and the patterns of his own actions' (Arendt, 1957: 86; Heisenberg, 1955: 17-18). The replacement of sense perception by scientific instruments had led to a 'universe whose qualities we know no more than the way they affect our measuring instruments' (Arendt, 1998: 261). Arendt stretched Heisenberg's point to frame the discoveries of twentieth-century physics to fit her claim that the human sciences were relying on outdated models of scientific understanding.

By pushing against notions of mind-independent objective reality, Heisenberg's uncertainty principle, fellow physicist Niels Bohr's notion of complementarity, and the field of quantum mechanics in general undermined dualist approaches to knowledge of the natural world and determinist treatments of matter and motion. The 'answers of science', Arendt claimed, would always 'remain replies to questions asked by men; the confusion in the issue of "objectivity" was to assume that there could be answers without questions and results independent of a question-asking being' (Arendt, 1958a: 577). Physics, she claimed, 'is no less a man-centered inquiry into what is than historical research' (1958a: 577). This was a rebuttal of logical positivist philosophy that claimed a neutral observational basis - an Archimedean point - for scientific theory. As with her treatment of the contemporary mathematization of philosophy, Arendt mapped this reading of modern physics onto the history of science. Drawing on Ernst Cassirer's Einstein's Theory of Relativity, she claimed that 'the parentage of modern relativism is not in Einstein but in Galileo and Newton' (Arendt, 1998: 264; Cassirer, 1953).

Modern physics, Arendt suggested, might erode instrumental understandings of nature and thus the human world. These were not fleeting concerns for her. In 'The conquest of space and the stature of man', published soon after the launch of the first American satellite in 1962 and the sending of probes to the moon by the Soviet Union, she ended on a pessimistic note that returned to the connection between science and totalitarianism she sketched in the $1950 \mathrm{~s}$. She suggested that pride in human powers might encourage a view of technology that no longer consciously extended material powers, but collapsed them into 'a large-scale biological process'. She cited Heisenberg's comment that from far away - or in her terms, from an earthalienated perspective - cars might become "“as inescapable a part of ourselves as the snail's shell is to its occupant"“ (Arendt, 2006c: 274). Alongside this gloomy prognosis, however, she also suggested that the Archimedean perspective might increase human stature by creating a 'new world view' that would be 'more geocentric and anthropomorphic' than the current one, but would not succumb to hubris in treating man as a quasi-divinity, 'the highest being there is' (2006c: 273). Such a world view would be heliocentric in recognizing that earth was not the centre of the universe, even while treating it as a 'home of mortal men', and would be 
anthropomorphic in counting 'mortality among the elementary conditions' of existence (2006c: 273). While underlining the need for understanding humanity's plural existence and grounding on the earth, Arendt was also suggesting that scientific development might bring about a shift towards non-instrumental ways of understanding human existence.

In treating Heisenberg's reflections as representative of modern physics, on the surface Arendt was following Heidegger's lead. Her suggestion that the threat of nuclear warfare might bring about a re-evaluation of the limits to human action and basic conditions of human mortality resembled Heidegger's emphasis on the growth of the 'saving power' at the point of 'extreme danger' (Arendt, 1990: 11-20; Heidegger, 1977: 28). Eager to use Heisenberg as a springboard with which to present his own treatment of the relationship between science and technology, Heidegger had encouraged the physicist to speak at the 1953 conference at which he presented 'Die Frage nach der Technik'.30 There he suggested - drawing on Heisenberg's claim that man encountered himself through the observation of nature - that the instrumentality of technology might raise the question of Being or existence as an issue by exacerbating man's fallenness (Heidegger, 1954: 100-5).

The central theme driving Arendt's treatment of science was the rise of earth alienation as a precondition for the instrumental exploitation of nature, increasingly eclipsed in the atomic era by the lack of instrumental control over the effects of scientific development. The heteronomy she posited at the heart of advances in human technical capacities shows the extent to which she adhered to certain tropes of German thought. She was in part historicizing and politicizing Heidegger's arguments about the inadequacy of conceptions of technology as a prosthetic instrument. As far as Arendt was concerned, hopes of reasserting instrumental, humanistic control of scientific and technological development were false and misleadingly anthropocentric. This separated her from contemporaries such as the young Jürgen Habermas who, though taking much from Heidegger's approach, was at times keen on the emancipatory potential of science (Habermas, 1969).

However, in focusing on historical changes in the way humans conceived of action, especially the notion of science as 'acting-into-nature', Arendt eschewed Heidegger's concern with the originary experience of Being. She stressed instead the implications of developments in the sciences in the nexus of technology and politics, mediated by the contingency that characterized action. This emphasis on action and event extended from the history of science to her view of the prospects for science, hoping that a surpassing of instrumentality and dualist ontologies would guard against the worst dangers of technology. This might even make possible, in a way philosophical argument could not, more meaningful conceptions of time and space that resisted the mathematization of the world.

\section{Conclusion}

Drawing on European and North American sources in the philosophy of science and popularizations by theoretical physicists, and combining technical and intellectual events, Arendt's depiction of scientific change was not wholly reductive. Nevertheless, it was synoptic and selective, anachronistically reading developments in modern physics - especially Einstein's theory of relativity - into early modern science. Focusing on a few key events and phenomena such as the invention of the telescope and mathematization, she used what one critic of anti-positivism has referred to as a 'block representation' of science, presenting scientific development as a series of revolutions and radical breaks (Galison, 1997: 793). After Kuhn, her treatment of the evolution of science appears dated (Kuhn, 1962). Nevertheless, categorizing her simply as another continental anti-positivist critic of science does not do justice to her interest in scientific discourse, and misses important differences between her approach and that of her contemporaries. 
An overwhelming emphasis on Arendt's theory of totalitarianism as a reference point for her writings from the 1950s has marginalized the connections she drew between science, history and human activity, and obscured significant elements of her treatment of action.31 The narrative of the history of science and technology she sketched in The Human Condition and elsewhere hinged on a series of contrasts: between the human artifice and earth alienation, language and mathematization, and action within bounds and unreflective Promethean endeavour. Since the early modern period, she suggested, the ways in which humans conceived action had been shaped by the standpoint of earth alienation provided by science, furnishing a faith in the instrumental manipulation of nature and human phenomena alike. Her history of science was part of a history of the changing forms of human action, skipping from the ancient world to the seventeenth century and then to modern physics and atomic science. From Galileo and Newton to space engineers and cyberneticians, scientific and technological advances had allowed man to act into nature from an alienated standpoint, setting off unpredictable processes that destabilized the world (Arendt, 1998: 52). An understanding of the history behind these developments, she suggested, was essential to interpreting the prospects for political action. Arendt was not concerned solely with undermining positivist treatments of science as a manifestation of human autonomy and rationality, nor with the social-scientific suppression of politics. She hoped to discern shifts within scientific research that might encourage noninstrumental and reflexive approaches to both politics and nature.

As this essay has suggested, Arendt's narrative of the history of science and technology cannot be explained satisfactorily through her theory of totalitarianism. It was fundamentally directed at Western societies, and specifically against the calculative forms of understanding cultivated by the behavioural sciences and analytical philosophy, whose rise she was seeking to historicize. On the surface, her views of technology had much in common with those expressed by Max Horkheimer and Adorno in Dialektik der Aufklärung (Adorno, 1947). However, rather than treating the heteronomy and instrumentality of science through the unfolding dialectic of reason, she separated reason from scientific development, instead constructing her analysis of the historical relationship between man and nature in terms of contingent events such as the invention of the telescope, and on the more ambivalent grounds of her history of action. Her attempt to rehabilitate an idiosyncratic but nevertheless humanist category of action, together with her commitment to deal with the history of science not only in terms of philosophy but practical technical development, also indicates that she was doing something quite different from Heidegger, the Frankfurt School and Karl Jaspers. An emphasis on action mitigated the Weberian pessimism of her treatment of the irreversibility of technological conditioning. Despite suggesting that the combination of technology and economic processes might lead to 'the deadliest, most sterile passivity history has ever known', she was also keen to stress that these changes did not 'mean that modern man has lost his capacities or is on the point of losing them' (Arendt, 1998: 322-3).

The connections between humanism, science and secularization illuminate themes in Arendt's thought that have recently begun to attract scholarly attention. 32 She avoided the pitfalls of teleological rationalization and modernization theories in viewing secularization as engendered by a combination of action and the confirmation technological innovations provided for scientific discoveries. This allowed her to explore the political implications of the constitution of the modern secular world in innovative ways not only in The Human Condition, but also in Between Past and Future (1961) and On Revolution (1963) (Arendt, 2006a: 91143; Arendt, 1990: 25-7, 101-4). While noting that world alienation and the resulting 'worldlessness' of atomized individuals could be superficially connected to Christian otherworldliness, she described the former as radically different in origin, and therefore character, from the latter. Only with the addition of the mathematization of time and space begun by physics, she argued, did this secular consciousness fully develop. One of the forms 
in which it manifested itself was the quasi-scientific and instrumental understanding of nature and history found in totalitarian ideology.

The themes of science and technology in Arendt's work in the 1950s therefore help place her in the midst of post-war debates about humanism and post-humanism. In her emphasis on action and the possibility of overcoming instrumentality through a reading of modern physics, she was less pessimistic than another student of Heidegger's, Karl Löwith, who took an almost cosmological perspective on the problems of anthropocentrism and historical development. 33 At the same time, the significance Arendt invested in the 'Archimedean point' shows the extent to which she thought technology dangerously accentuated the Roman assumption 'that man is the highest being we know of' (Arendt, 2006c: 260). However, as her response to the question, 'Has man's conquest of space increased or diminished his stature?' posed by the journal for which she wrote 'The conquest of space and the stature of man' (1963), suggests, Arendt was still fundamentally concerned with the rehabilitation of a chastened form of humanism (Arendt, 2006c). Her claims about the dignity of the human were tied to the fate of action, understood historically, in an increasingly 'worldless' world. Arendt drew together the epistemological practices of the free and unfree world in a global process that suggested that spaces for political freedom were shrinking in Western democracies as much as in the communist bloc. Science and technology, entangled with secularization, were central components of this narrative.

\section{Notes}

1. British historian Elie Kedourie noted in the Manchester Guardian Weekly that 'some of Miss Arendt's most brilliant chapters' dealt with the transformation of scientific thought (Arendt, 1958c: 0009dff). See also Arendt (1958c: 0048dff).

2. See, for example, Canovan, (1994: 76-81). The few studies that discuss Arendt's perspectives on science and technology are directed toward establishing her contemporary relevance, rather than charting their development in context: for example, Tijmes (1992). For a comprehensive survey aimed at gleaning ecological insights from Arendt's work see Macauley (1996). For a convincing historical analysis of Arendt's writings on technology that says little about her sources or interlocutors, see Cooper (1988).

3. The influence of Arendt's treatment of the inmate can be seen in Giorgio Agamben's notion of 'bare life' (Agamben, 2000: 14-44).

4. A translated version of 'Ideology and terror' was added to the first German edition of The Origins of Totalitarianism (1955), and then to the second English-language edition, published in 1958. For a discussion of the broader significance of 'Ideology and terror' to Arendt's theory of totalitarianism, see Tsao (2002: 604-12).

5. This determinist, scientistic picture leaned heavily on Engels' depiction of Marx as the Darwin of the human world, and the interpretations presented by Marxist theorists of the Second International. For Arendt's reference to Darwin, see Arendt (2005f: 288, n21).

6. While Arendt's implicit points of reference for polemical treatments of Marx were contemporary theorists such as Karl Popper and Jacob Talmon, she more explicitly criticized 'exCommunists' turned Cold Warriors. See Arendt (2005h; 2005g).

7. Contemporary modernization theory exemplified this. See Engerman (2003); Gilman (2007).

8. Arendt had been present at a key moment in the articulation of the 'end of ideology' claim. At the September 1955 meeting of the Congress for Cultural Freedom (CCF) in Milan, a number of thinkers had provocatively declared their agreement that the societies of the Free World - America and Western Europe - were witnessing an end to the age of ideological politics. What would remain, they suggested, would be the self-interested and autonomous 
subjects assumed by the empirical and behavioural political sciences. See Brick (1998: 34, 37); Dittberner (1979); Waxman (1969).

9. Max Scheler had argued in 1926 that the technological will to power had altered humanity so much that the term Homo sapiens should be changed to Homo faber, or 'working being' (Scheler, 1926: 447).

10. In depicting the psychological effects of modern society and the Prometheanism generated by instrumental modes of conceiving the world, Arendt's analysis resembled that of the Frankfurt School. Her critique of Marx, however, set her apart from thinkers like Theodor Adorno and Herbert Marcuse. See, for example, Adorno (2001); Horkheimer (1947); Fromm (1942).

11. For the most thorough examination of Arendt's use of discourses of mass society in the secondary literature, see Baehr $(2007 ; 2010)$.

12. The popularity of these discourses in Germany contributed to the widespread acceptance of a notion that historian Richard Beyler has aptly termed the 'demon of technology' (Beyler, 2003: 2).

13. See Herf (1984). For the relationship between Jünger and Heidegger, see Zimmerman (1990) and Gusejnova (2006).

14. This text is kept, along with the rest of her library, in the Stevenson Library, Bard College, New York.

15. For perhaps the most famous example of this, see Schmitt (1950). Even Karl Jaspers, who was favourably disposed towards the United States, wrote in a letter to Arendt in 1950 that even if heightening tensions in Korea did not lead to war, it would at least 'teach the Americans that a world order can't be attained with technology alone' (Arendt and Jaspers, 1992: 155).

16. For more on this subject, see Morat (2012).

17. Jaspers, in one of the first major treatises to engage with questions of German guilt after the war, adopted a similar approach. See Jaspers (1946). See also Rabinbach (2000a; 2000b)

18. In The Human Condition Arendt stated that despite differing from Weber over the meaning of secularization, she did not want to 'deny the greatness' of his 'discovery of the enormous power that comes from an otherworldliness directed toward the world'. She had cited his interpretation of the Protestant ethic as early as 1930, in a review of Karl Mannheim's Ideologie und Utopie (1929). See Arendt (1998: 252, n2; 2005e: 40) and Weber (1904). As Peter Baehr has noted, 'shell as hard as steel' is a more accurate translation of Weber's original phrase 'stahlhartes Gehäuse' than the famous rendering of it as 'iron cage' by Talcott Parsons, which has long since become conventional in social thought. See Baehr (2001: 153-4).

19. This dating is suggested by a heavily underlined copy of the first edition of the Einführung in die Metaphysik, as well as her correspondence with Jaspers and Blücher in addition to Heidegger. For a succinct summary of Heidegger's 'Kehre' (turn) see Gordon (2008: 226).

20. See also the essays collected in Mariner and Piehler (2009).

21. For a useful treatment of Jaspers' thoughts on nuclear technology, see Beyler (2003: 228). For a general overview of Jaspers' thought, see Thornhill (2002).

22. The original radio broadcast was published in 1956. References during the following discussion refer to the English version, The Future of Mankind, whose publication Arendt helped facilitate through the University of Chicago Press. See Jaspers $(1957 ; 1958 ; 1961)$ and Arendt (1959).

23. For more on the anti-nuclear movement in West Germany, see Nehring (2004). 
24. Arendt was dismissive of psychoanalysis. See Arendt and Jaspers (1992: 213). Her biography of the Jewish salon hostess Rahel Varnhagen critiqued Romantic notions of 'intimacy' in detail. See Arendt (1974).

25. This text was based on lectures he gave in 1953 .

26. For a critique of the neo-Aristotelian reading of Arendt put forward by theorists such as Habermas, see Villa (1996: 78).

27. For this she drew upon Sambursky's The Physical World of the Greeks, describing his overview of Greek attitudes to the natural world as 'very instructive' (Sambursky, 1956; cf. Koyré, 1957: 8).

28. For more on this interpretation of Galileo, see Breuer (2009: 230).

29. Lüst (2004: 15-23); For Arendt's contemporaneous references to Heisenberg, see Arendt (1998: 261; 1957: 86; 2006b: 86).

30. On Heidegger's engagement with Heisenberg, see Carson (2010b: 495), Pöggeler (1993: 27-34) and Chevalley (1992: 352).

31. For examples of a focus on totalitarianism, see Villa (1999) and Hayden (2009).

32. For two excellent explorations of the topic of secularization in Arendt's work, see Brient (2000: 515) and Moyn (2008).

33. Löwith (1949). On Löwith, see Habermas (1985) and Wolin (2003). For mid-twentiethcentury European debates over humanism, see Geroulanos (2010: 209-304) and Rockmore (1995).

\section{References}

Adorno TW (1947) Dialektik der Aufklärung. Amsterdam: Querido Verlag.

Adorno TW (2001) The Culture Industry. London: Routledge.

Agamben G (2000) Means Without End: Notes on Politics. Minneapolis: University of Minnesota Press.

Arendt H (1951a) Science folder. Washington, DC: Library of Congress, Arendt Papers, Box 84.

Arendt H (1951b) The Origins of Totalitarianism. New York: Harcourt.

Arendt H (1951c) Project: Totalitarian elements in Marxism. Washington, DC: Library of Congress, Arendt Papers, Box 64.

Arendt H (1951d) Alexandre Koyré 1951-1963. Washington, DC: Library of Congress, Arendt Papers, Box 12.

Arendt H (1952) The impact of Marx. Washington, DC: Library of Congress, Arendt Papers, Box 68. Arendt H (1953) Ideology and terror: a novel form of government. Review of Politics 15(3): 303-27.

Arendt H (c. 1956) Copernicus and Galileo. Washington, DC: Library of Congress, Arendt Papers, Box 84.

Arendt H (1957) History and immortality. Partisan Review 24(1): 11-35.

Arendt H (1958a) The modern concept of history. Review of Politics 20(4): 570-90.

Arendt H (1958b) Totalitarian imperialism: reflections on the Hungarian Revolution. Journal of Politics 20(1): 5-43.

Arendt H (1958c) Clippings of reviews of The Human Condition. Washington, DC: Library of Congress, Arendt Papers, Box 86.

Arendt H (1959) Letter to Alexander Morin, 8 March. Washington, DC: Library of Congress, Arendt Papers, Box 34, mss. 00048-00049.

Arendt H (1974) Rahel Varnhagen: The Life of a Jewess. San Diego: Harcourt Brace Jovanovich.

Arendt H (1990) On Revolution. Harmondsworth: Penguin.

Arendt H (1998) The Human Condition. Chicago: University of Chicago Press. 
Arendt H (2002a) Karl Marx and the tradition of Western political thought. Social Research of Politics 69(2): 273-319.

Arendt H (2002b) Denktagebuch: 1950-1973. Munich: Piper.

Arendt H (2005a) Approaches to the 'German problem. In: J Kohn (ed.) Essays in Understanding, 1930-1954: Formation, Exile, and Totalitarianism. New York: Schocken Books, pp. 106-20.

Arendt H (2005b) Concern with politics in recent European philosophical thought. In: J Kohn (ed.) Essays in Understanding, 1930-1954: Formation, Exile, and Totalitarianism. New York: Schocken Books, pp. 428-47.

Arendt H (2005c) Dream and nightmare. In: J Kohn (ed.) Essays in Understanding, 1930-1954: Formation, Exile, and Totalitarianism. New York: Schocken Books, pp. 409-17. Arendt H (2005d) Europe and the atom bomb. In: J Kohn (ed.) Essays in Understanding, 1930-1954: Formation, Exile, and Totalitarianism, New York: Schocken Books, pp. 418-22. Arendt H (2005e) Philosophy and sociology. In: J Kohn (ed.) Essays in Understanding, 1930-1954: Formation, Exile, and Totalitarianism. New York: Schocken Books, pp. 28-43.

Arendt H (2005f) Religion and politics. In: J Kohn (ed.) Essays in Understanding, 1930-1954: Formation, Exile, and Totalitarianism. New York: Schocken Books, pp. 368-90.

Arendt H (2005g) The eggs speak up. In: J Kohn (ed.) Essays in Understanding, 1930-1954: Formation, Exile, and Totalitarianism. New York: Schocken Books, pp. 270-84.

Arendt H (2005h) The ex-Communists. In: J Kohn (ed.) Essays in Understanding, 1930-1954: Formation, Exile, and Totalitarianism. New York: Schocken Books, pp. 391-400.

Arendt H (2005i) The ivory tower of common sense. In: J Kohn (ed.), Essays in Understanding, 1930-1954: Formation, Exile, and Totalitarianism. New York: Schocken Books, pp. 194-6. Arendt H (2005j) The threat of conformism. In: J Kohn (ed.) Essays in Understanding, 1930-1954: Formation, Exile, and Totalitarianism. New York: Schocken Books, pp. 423-7.

Arendt H (2005k) What is existential philosophy?' In: J Kohn (ed.) Essays in Understanding, 1930-1954: Formation, Exile, and Totalitarianism. New York: Schocken Books, 163-87.

Arendt H (20051) From Hegel to Marx. In: J Kohn (ed.) The Promise of Politics. New York: Schocken Books, pp. 70-80.

Arendt H (2006a) Between Past and Future: Eight Exercises in Political Thought. New York: Penguin.

Arendt H (2006b) The concept of history: ancient and modern. In: H Arendt, Between Past and Future: Eight Exercises in Political Thought. New York: Penguin.

Arendt H (2006c) The conquest of space and the stature of man. In: H Arendt, Between Past and Future: Eight Exercises in Political Thought. New York: Penguin.

Arendt H (2006d) Tradition and the modern age. In: H Arendt, Between Past and Future: Eight Exercises in Political Thought. New York: Penguin.

Arendt H and Blücher H (2000). Within Four Walls: The Correspondence between Hannah Arendt and Heinrich Blücher, 1936-1968. Harcourt: London.

Arendt H and Jaspers K (1992) Hannah Arendt and Karl Jaspers: Correspondence: 1926-1969. New York: Harcourt Brace Jovanovich.

Baehr P (2001) The 'iron cage' and the 'shell as hard as steel': Parsons, Weber, and the Stahlhartes Gehäuse metaphor in The Protestant Ethic and the Spirit of Capitalism. History and Theory 40(2): 153-69.

Baehr P (2007) The 'masses' in Hannah Arendt's theory of totalitarianism. The Good Society 16(2): 12-18.

Baehr P (2010) Hannah Arendt, Totalitarianism, and the Social Sciences. Stanford, CA: Stanford University Press.

Beyler R (2003) The demon of technology, mass society, and atomic physics in West Germany, 1945-1957. History and Technology 19(3): 227-39. 
Breuer S (2009) The nihilism of speed: on the work of Paul Virilio. In: H Rosa and WE Scheuerman (eds) High-Speed Society: Social Acceleration, Power, and Modernity. University Park, PA: Pennsylvania University Press, pp. 215-41.

Brick H (1998) Age of Contradiction: American Thought and Culture in the 1960s. New York: Twayne Publishers.

Brient E (2000) Hans Blumenberg and Hannah Arendt on the 'unworldly worldliness' of the modern age. Journal of the History of Ideas 61(3): 513-30.

Burtt EA (1932) The Metaphysical Foundations of Modern Science. New York: Anchor.

Canovan M (1994) Hannah Arendt: A Reinterpretation of her Political Thought. Cambridge: Cambridge University Press.

Carson C (2010a) Heisenberg in the Atomic Age: Science and the Public Sphere. Cambridge: Cambridge University Press.

Carson C (2010b) Science as instrumental reason: Heidegger, Habermas, Heisenberg. Continental Philosophical Review 42(4): 483-509.

Cassirer E (1953) Einstein's Theory of Relativity. New York: Dover Publications.

Chevalley C (1992) Heidegger and the physical sciences. In: C Macann (ed.) Martin Heidegger: Critical Assessments, vol. 4. London: Routledge, pp. 342-64.

Cooper B (1988) Action into nature: Hannah Arendt's reflections on technology. In: RB Day, R Beiner and J Masciulli (eds) Democratic Theory and Technological Society. New York: ME Sharpe, pp. 316-35.

Dijk P van (2000) Anthropology in the Age of Technology: The Philosophical Contribution of Günther Anders. Amsterdam: Rodopi.

Dittberner JL (1979) The End of Ideology and American Social Thought, 1930-1960. Ann Arbor: UMI Research Press.

Engerman D (2003) Staging Growth: Modernization, Development, and the Global Cold War. Amherst, MA: University of Massachusetts Press.

Fromm E (1942) The Fear of Freedom. London: Routledge and Kegan Paul.

Gaddis JL (2005) Strategies of Containment: A Critical Appraisal of American National Security Policy during the Cold War. Oxford: Oxford University Press.

Galison P (1997) Image and Logic: A Material Culture of Microphysics. Chicago: University of Chicago Press.

Geroulanos S (2010) An Atheism That is Not Humanist Emerges in French Thought. Stanford, CA: Stanford University Press.

Gilman N (2007) Mandarins of the Future: Modernization Theory in Cold War America. Baltimore: The Johns Hopkins University Press.

Gordon P (2008) Neo-Kantianism and the politics of Enlightenment. Philosophical Forum 39(2): 223-38.

Gusejnova D (2006) Concepts of culture and technology in Germany, 1916-1933: Ernst Cassirer and Oswald Spengler. Journal of European Studies 36(1): 5-30.

Habermas J (1985) Karl Löwith: stoic retreat from historical consciousness. In: T McCarthy (ed.) Philosophical-Political Profiles, Cambridge, MA: MIT Press, pp. 79-88.

Habermas J (1969) Erkenntnis und Interesse. In: J Habermas, Technik und Wissenschaft als 'Ideologie', Suhrkamp Verlag: Frankfurt, pp. 146-68.

Hayden P (2009) Political Evil in a Global Age: Hannah Arendt and International Theory. New York: Routledge.

Heidegger M (1953) Einführung in die Metaphysik. Tübingen: Max Niemeyer Verlag.

Heidegger M (1954) Die Frage nach der Technik. In: Vortrage und Aufsatze, Pfullingen: Neske.

Heidegger M (1977) The question concerning technology. In: The Question Concerning Technology, and Other Essays. New York: Garland Publishing, pp. 3-35. 
Heidegger M (2000) Introduction to Metaphysics. New Haven, CT: Yale University Press. Heisenberg W (1955) Das Naturbild der heutigen Physik. Hamburg: Rowohlt.

Herf J (1984) Reactionary Modernism: Technology, Culture, and Politics in Weimar and the Third Reich. Cambridge: Cambridge University Press.

Horkheimer M (1947) Eclipse of Reason. Oxford: Oxford University Press.

Isaac J (2005) W.V. Quine and the origins of analytic philosophy in the United States. Modern Intellectual History 2(2): 205-34.

Jaspers K (1946) Die Schuldfrage: ein Beitrag zur deutschen Frage. Zürich: Artemis-Verlag. Jaspers K (1951) Rechenschaft und Ausblick. Munich: Piper.

Jaspers K (1957) Die Atombombe und die Zukunft des Menschen: ein Radiovortag. Munich: Piper.

Jaspers K (1958) Die Atombombe und die Zukunft des Menschen: politisches Bewusstsein in unserer Zeit. Munich: Piper.

Jaspers K (1961) The Future of Mankind. Chicago: University of Chicago Press.

Koyré A (1957) From the Closed World to Infinite Universe. Baltimore, MD: The Johns Hopkins University Press.

Kuhn TS (1962) The Structure of Scientific Revolutions. Chicago: University of Chicago Press. Leslie SW (1993) The Cold War and American Science: The Military-Industrial-Academic Complex at MIT and Stanford. New York: Columbia University Press.

Löwith K (1949) Meaning in History: The Theological Implications of the Philosophy of History. Chicago: University of Chicago Press.

Lüst R (2004) Heisenberg and the scientist's responsibility. In: GW Buschhorn and J Wess (eds) Fundamental Physics: Heisenberg and Beyond. London: Springer, pp. 15-23.

Macauley D (1996) Hannah Arendt and the politics of place: from earth alienation to oikos. In: Minding Nature: Philosophers of Ecology. New York: Guilford Publications, 102-33.

Mariner RB and GK Piehler (2009) The Atomic Bomb and American Society: New Perspectives. Knoxville: University of Tennessee Press.

Morat D (2012) No inner remigration: Martin Heidegger, Ernst Jünger, and the early Federal Republic of Germany. Modern Intellectual History 9(3): 661-79.

Moyn S (2008) Hannah Arendt on the secular. New German Critique 35(3): 71-96.

Nehring H (2004) Cold War, apocalypse and peaceful atoms: interpretations of nuclear energy in the British and West German anti-nuclear weapons movements, 1955-1964. Historical Social Research 29(3): 150-70.

Pitkin HF (1998) The Attack of the Blob: Hannah Arendt's Concept of the Social. Chicago: University of Chicago Press.

Pöggeler O (1993) The hermeneutics of the technological world: The Heidegger-Heisenberg dispute. International Journal of Philosophical Studies 1(1): 21-48.

Rabinbach A (2000a) In the Shadow of Catastrophe: German Intellectuals between Apocalypse and Enlightenment. Berkeley: University of California Press.

Rabinbach A (2000b) The German as pariah: Karl Jaspers's The Question of German Guilt. In: In the Shadow of Catastrophe: German Intellectuals between Apocalypse and Enlightenment. Berkeley: University of California Press, pp. 129-65.

Rockmore T (1995) Heidegger and French Philosophy: Humanism, Antihumanism, and Being. London: Routledge.

Sambursky S (1956) The Physical World of the Greeks. London: Routledge and Paul.

Scheler M (1926) Die Wissensformen und die Gesellschaft. Leipzig: Der neue Geist Verlag.

Schmitt C (1950) Der Nomos der Erde: im Völkerrecht des Jus Publicum Europaeum. Cologne: Greven.

Thornhill C (2002) Karl Jaspers: Politics and Metaphysics. London: Routledge. 
Tsao R (2002) The three phases of Arendt's theory of totalitarianism. Social Research 69(1): 604-12.

Tijmes P (1992) The Archimedean point and eccentricity: Hannah Arendt's philosophy of science and technology. Inquiry 35(3): 389-406.

Villa DR (1996) Arendt and Heidegger: The Fate of the Political. Princeton, NJ: Princeton University Press.

Villa DR (1999) Politics, Philosophy, Terror: Essays on the Thought of Hannah Arendt. Princeton, NJ: Princeton University Press.

Waxman CI (1969) The End of Ideology Debate. New York: Funk and Wagnalls.

Weber M (1904) Die Protestantische Ethik und der Geist des Kapitalismus. Archiv für Sozialwissenschaft und Sozialpolitik 1.

Whitehead AN (1920) The Concept of Nature. Cambridge: Cambridge University Press.

Wolin R (2003) Heidegger's Children: Hannah Arendt, Karl Löwith, Hans Jonas, and Herbert Marcuse. Princeton, NJ: Princeton University Press.

Young-Bruehl E (1983) Hannah Arendt: For Love of the World. New Haven, CT: Yale University Press.

Zimmerman ME (1990) Heidegger's Confrontation with Modernity: Technology, Politics, and Art. Bloomington: Indiana University Press. 